Check for updates

Cite this: RSC Adv., 2018, 8, 26325

\title{
High-pressure synthesis and electrochemical properties of tetragonal $\mathrm{LiMnO}_{2} \dagger$
}

\begin{abstract}
Takeshi Uyama, (D) *a Kazuhiko Mukai (D) a and Ikuya Yamada (D) ${ }^{\text {b }}$
Tetragonal structured $\mathrm{LiMnO}_{2}\left(\mathrm{t}-\mathrm{LiMnO}_{2}\right)$ samples were synthesized under pressures above $8 \mathrm{GPa}$ and investigated as a positive electrode material for lithium-ion batteries. Rietveld analyses based on $\mathrm{X}$-ray diffraction measurements indicated that $\mathrm{t}-\mathrm{LiMnO}_{2}$ belongs to a $\gamma-\mathrm{LiFeO}_{2}$-type crystal structure with the $14_{1}$ /amd space group. The charge capacity during the initial cycle was $37 \mathrm{~mA} \mathrm{~h} \mathrm{~g}{ }^{-1}$ at $25{ }^{\circ} \mathrm{C}$, but improved to $185 \mathrm{~mA} \mathrm{~h} \mathrm{~g}^{-1}$ at $40{ }^{\circ} \mathrm{C}$ with an average voltage of $4.56 \mathrm{~V} \mathrm{vs}$. $\mathrm{Li}^{+} / \mathrm{Li}$. This demonstrated the superiority of $\mathrm{t}-\mathrm{LiMnO}_{2}$ over other lithium manganese oxides in terms of energy density. The $\mathrm{X}$-ray diffraction measurements and Raman spectroscopy of cycled $\mathrm{t}-\mathrm{LiMnO}_{2}$ indicated an irreversible transformation from the $\gamma$ - $\mathrm{LiFeO}_{2}$-type structure into a $\mathrm{Li}_{x} \mathrm{Mn}_{2} \mathrm{O}_{4}$ spinel structure by the displacement of $25 \%$ of the $\mathrm{Mn}$ ions to vacant octahedral sites through adjacent octahedral sites.
\end{abstract}

Received 1st May 2018

Accepted 14th July 2018

DOI: 10.1039/c8ra03722a

rsc.li/rsc-advances

(Fig. 1b), has a large $Q_{\text {theo }}$ of $458 \mathrm{~mA} \mathrm{~h} \mathrm{~g}{ }^{-1}$. However, $\mathrm{Li}_{2} \mathrm{MnO}_{3}$ is essentially electrochemically inactive because of the difficulty in further oxidizing the $\mathrm{Mn}^{4+}$ species, ${ }^{9}$ unless a proton exchange ${ }^{10}$ and/or an oxygen loss $^{11}$ in its lattice proceed during the initial charge reaction. An orthorhombic $\mathrm{LiMnO}_{2}\left(\mathrm{o}-\mathrm{LiMnO}_{2}\right)^{12-18}$ and a monoclinic $\mathrm{LiMnO}_{2}\left(\mathrm{~m}-\mathrm{LiMnO}_{2}\right)^{4,19}$ have a formal oxidation state of $\mathrm{Mn}^{3+}$ (Fig. 1c and d) and their charge capacities $\left(Q_{\text {cha }} \mathrm{s}\right)$ reach a maximum of $230 \mathrm{~mA} \mathrm{~h} \mathrm{~g}{ }^{-1}$ for $\mathrm{o}^{-\mathrm{LiMnO}_{2}}$ and $270 \mathrm{~mA} \mathrm{~h} \mathrm{~g}{ }^{-1}$ for $\mathrm{m}-\mathrm{LiMnO}_{2}$. However, delithiated o- and $\mathrm{m}$ $\mathrm{LiMnO}_{2}$ can be irreversibly and spontaneously transformed into a $\mathrm{Li}_{x} \mathrm{Mn}_{2} \mathrm{O}_{4}$ spinel; thus, the $Q_{\text {recha }}$ values for both of these compounds decrease in a manner similar to that seen in $\mathrm{LiMn}_{2} \mathrm{O}_{4}$ as the changes in the charge and discharge curves echo those of $\mathrm{Li}_{x} \mathrm{Mn}_{2} \mathrm{O}_{4} \cdot{ }^{12,15-19}$ In contrast, O2-type layered $\mathrm{Li}_{2 / 3}\left[\mathrm{Li}_{1 /}\right.$ $\left.{ }_{6} \mathrm{Mn}_{5 / 6}\right] \mathrm{O}_{2}$ (ref. 20) and $\mathrm{Li}_{p}\left[\mathrm{Li}_{1 / 4} \mathrm{Mn}_{3 / 4}\right] \mathrm{O}_{2}$ with $p<1$ (ref. 21) (Fig. 1e and $\mathrm{f}$ ) were reported to display good cycleability without transformation into the $\mathrm{Li}_{x} \mathrm{Mn}_{2} \mathrm{O}_{4}$ spinel. The oxygen stacking, which is $A B A C A B$ for $\mathrm{Li}_{2 / 3}\left[\mathrm{Li}_{1 / 6} \mathrm{Mn}_{5 / 6}\right] \mathrm{O}_{2}$ and $\mathrm{Li}_{p}\left[\mathrm{Li}_{1 / 4} \mathrm{Mn}_{3 / 4}\right] \mathrm{O}_{2}$ (unlike the $\mathrm{ABCABC}$ stacking seen in $\mathrm{m}-\mathrm{LiMnO}_{2}$ ), plays an important role in this. As a result, the $Q_{\text {recha }}$ is $150 \mathrm{~mA} \mathrm{~h} \mathrm{~g}{ }^{-1}$ for $\mathrm{Li}_{2 / 3}\left[\mathrm{Li}_{1 / 6} \mathrm{Mn}_{5 / 6}\right]$ $\mathrm{O}_{2}$ and $200 \mathrm{~mA} \mathrm{~h} \mathrm{~g}{ }^{-1}$ for $\mathrm{Li}_{p}\left[\mathrm{Li}_{1 / 4} \mathrm{Mn}_{3 / 4}\right] \mathrm{O}_{2}$. In the initial cycle, the $Q_{\text {cha }}$ ranges between 20 and $50 \mathrm{~mA} \mathrm{~h} \mathrm{~g}^{-1}$, and is smaller than the $Q_{\text {recha }}$ due to lithium deficiency in these compounds. This triggers a decrease in the $Q_{\text {recha }}$ whenever these compounds are used in full cells with negative electrode materials that do not contain residual lithium, e.g. graphite and silicon.

Sugiyama et al. synthesized a tetragonal $\mathrm{LiMnO}_{2}\left(\mathrm{t}-\mathrm{LiMnO}_{2}\right)$ from $\mathrm{o}-\mathrm{LiMnO}_{2}$ by a high-pressure and high-temperature method, with pressures between 4 and $6 \mathrm{GPa}$ and temperatures between 900 and $1200{ }^{\circ} \mathrm{C}^{22}$ Rietveld analyses based on Xray diffraction (XRD) measurements showed that $\mathrm{t}-\mathrm{LiMnO}_{2}$ has a $\gamma$-LiFeO ${ }_{2}$-type structure with $I_{1} /$ amd space group (Fig. $1 \mathrm{~g}$ ). In this structure, $\mathrm{MnO}_{6}$ octahedra form a three-dimensional

${ }^{a}$ Toyota Central Research and Development Laboratories, Inc., Nagakute, Aichi, ${ }^{b}$ Department of Materials Science, Graduate School of Engineering, Osaka Prefecture University, 1-2 Gakuen, Sakai, Osaka 599-8590, Japan

$\dagger$ Electronic supplementary information (ESI) available: Cycle performances at $25{ }^{\circ} \mathrm{C}$ of the o-LiMnO ${ }_{2}$, LMO (5 GPa), LMO (8 GPa) and LMO (12 GPa) samples, charge and discharge curves of the lithium cells with the LMO (5 GPa) and LMO $(8 \mathrm{GPa})$ samples operated at $40{ }^{\circ} \mathrm{C}$, structural parameters of the LMO $(5$ GPa) and LMO (8 GPa) samples, Raman spectrum of the charged LMO (12 GPa) sample, Raman spectra of the cycled LMO (5 GPa) and LMO (8 GPa) samples, and Raman spectra of PTFE and AB. See DOI: 10.1039/c8ra03722a 
framework by sharing their edges, resulting in a straight channel of $\mathrm{Li}^{+}$ions along the [111] direction. This configuration between $\mathrm{MnO}_{6}$ octahedra and $\mathrm{Li}^{+}$ions is clearly different from the framework composed of two-dimensional $\mathrm{MnO}_{6}$ layers in the $\mathrm{LiMnO}_{2}$-based compounds mentioned above (see Fig. 1b-f); rather, the crystal structure of $\mathrm{t}-\mathrm{LiMnO}_{2}$ is comparable to that of $\mathrm{LiMn}_{2} \mathrm{O}_{4}$. Therefore, in addition to the high $Q_{\text {theo }}$ $\left(285 \mathrm{~mA} \mathrm{~h} \mathrm{~g}^{-1}\right)$, t-LiMnO ${ }_{2}$ is also a desirable material for understanding the relationships between the structural and electrochemical properties in a group of LMOs.

Despite its unique crystallographic character, the electrochemical properties of $\mathrm{t}-\mathrm{LiMnO}_{2}$ remain unclear. This is likely due to the difficulty in conducting large-scale synthesis via the high-pressure method because a tiny sample container is generally used to generate high pressure $(>10 \mathrm{GPa}) \cdot{ }^{23}$ However, recent technological developments, including the use of belttype and multi-anvil-type equipment, enabled us to evaluate a variety of functional materials. ${ }^{24-27}$ In the current study, we synthesized t- $\mathrm{LiMnO}_{2}$ under high pressures up to $12 \mathrm{GPa}$ and reported its electrochemical performance as a positive electrode material for LIBs for the first time, in order to clarify the relationship between the structural and electrochemical properties of t-LiMnO ${ }_{2}$. The $Q_{\text {cha }}$ of t-LiMnO ${ }_{2}$ reached $185 \mathrm{~mA} \mathrm{~h} \mathrm{~g}^{-1}$ with an $E_{\text {ave }}$ of $4.56 \mathrm{~V}$ upon increasing the operating temperature to $40{ }^{\circ} \mathrm{C}$, which is superior to other LMOs. This information will be helpful in designing advanced LMOs with high $W$ in terms of their structure and composition.

\section{Experimental}

\section{Sample preparations}

$\mathrm{t}$-LiMnO${ }_{2}$ was synthesized from o-LiMnO ${ }_{2}$ by the high-pressure and high-temperature method using a Walker-type apparatus. ${ }^{28}$ $\mathrm{o}-\mathrm{LiMnO}_{2}$ was first synthesized via solid-state reactions. Stoichiometric amounts of $\mathrm{LiOH} \cdot \mathrm{H}_{2} \mathrm{O}$ (Wako Pure Chemical Industries Ltd.) and $\mathrm{Mn}_{2} \mathrm{O}_{3}$ (Wako Pure Chemical Industries Ltd.) were mixed in ethanol and the mixture was dried and pressed into a 5 $\mathrm{mm}$-thick pellet with a diameter of $15 \mathrm{~mm}$. The pellet was heated at $1000{ }^{\circ} \mathrm{C}$ for $12 \mathrm{~h}$ under argon gas flow at a heating rate of $200{ }^{\circ} \mathrm{C} \mathrm{h}^{-1}$ and a cooling rate of $1{ }^{\circ} \mathrm{C} \mathrm{min}^{-1}$. The obtained $\mathrm{o}^{-}$ $\mathrm{LiMnO}_{2}$ was crushed and re-pressed into a $5 \mathrm{~mm}$-thick pellet with a diameter of $2.8 \mathrm{~mm}$ before being packed into a platinum capsule. The capsule was then placed in a BN insulation sleeve, which was placed in a cylindrical graphite heater. The assembled sample was placed in a ( $\mathrm{Mg}, \mathrm{Co}) \mathrm{O}$ octahedral pressure medium with side lengths of $14 \mathrm{~mm}$. The (Mg, Co)O octahedra were slowly compressed to 5,8 , or $12 \mathrm{GPa}$ by eight tungsten carbide truncated $8 \mathrm{~mm}$ edges. The compressed samples were then heated at $1000{ }^{\circ} \mathrm{C}$ for $30 \mathrm{~min}$ and subsequently quenched to room temperature, and the pressure was slowly released until an ambient pressure was achieved. Hereafter, the o- $\mathrm{LiMnO}_{2}$ samples treated at 5, 8, and $12 \mathrm{GPa}$ are represented as LMO (5 GPa), LMO (8 GPa), and LMO (12 GPa), respectively, to avoid a misunderstanding of the actual phase purity. A powder sample of $\mathrm{LiMn}_{2} \mathrm{O}_{4}$ was also synthesized by heating a mixture of $\mathrm{LiOH} \cdot \mathrm{H}_{2} \mathrm{O}$ and $\mathrm{MnO}_{2}$ (Kojundo Chemical Laboratory Co., Ltd.) at $1000{ }^{\circ} \mathrm{C}$ for $12 \mathrm{~h}$ under oxygen gas flow. 


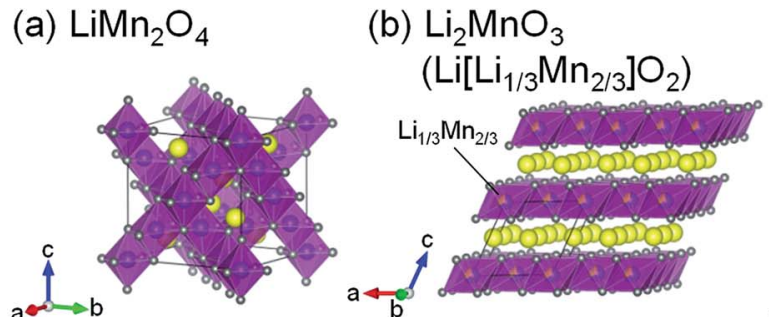

(e) $\mathrm{Li}_{2 / 3}\left[\mathrm{Li}_{1 / 6} \mathrm{Mn}_{5 / 6}\right] \mathrm{O}_{2}$

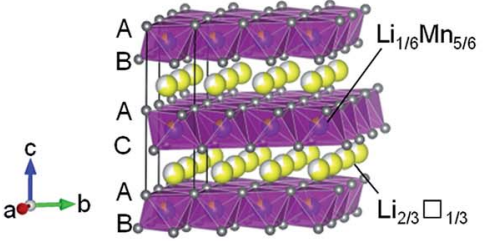

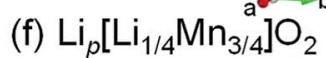

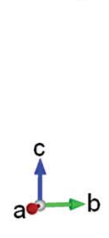

(c) $0-\mathrm{LiMnO}_{2}$

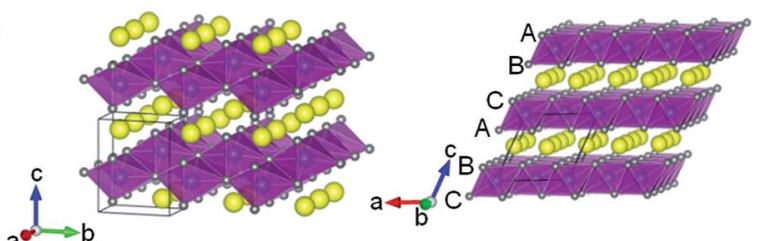

(d) $\mathrm{m}-\mathrm{LiMnO}_{2}$

(g) $\mathrm{t}-\mathrm{LiMnO}_{2}$

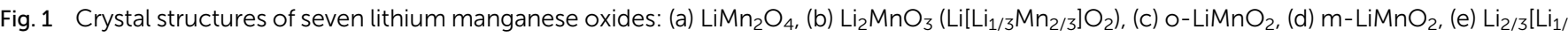

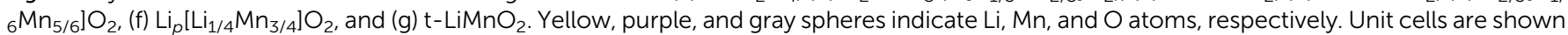
by the solid black lines. The oxygen stacking manner is shown in Fig. $1 d-f$.

\section{Characterization of the samples}

The powder samples of o-LiMnO 2 , LMO (5 GPa), LMO (8 GPa), and LMO (12 GPa) were characterized by scanning electron microscopy (SEM), synchrotron XRD measurements, and Raman spectroscopy. The SEM images were recorded using an S-3600N (Hitachi High-Technologies, Company Ltd.) at an accelerating voltage of $15 \mathrm{kV}$. The XRD measurements were conducted at a BL5S2 beamline available at the Aichi Synchrotron Radiation Center. The samples were packed into borosilicate glass capillary tubes with a diameter of $0.3 \mathrm{~mm}$ (WJM-Glas Müller $\mathrm{GmbH}$ ). The XRD patterns were collected using a two-dimensional detector, PILATUS $100 \mathrm{~K}$ (Dectris Ltd., Baden-Daettwil), over a $2 \theta$ range between $5^{\circ}$ and $95^{\circ}$. The incident X-ray wavelength $(\lambda)$ was determined to be $0.799323(2)$ or $0.799670(2) \AA$ from the XRD patterns of silicon powders (NIST 640d). Rietveld analyses and drawings of crystal structures were carried out using the RIETANFP $^{29}$ and VESTA softwares, ${ }^{30}$ respectively. The Raman spectra were collected on an NRS-3300 (Jasco Co. Ltd.) using an excitation laser wavelength of $532 \mathrm{~nm}$ and a laser power of $0.1 \mathrm{~mW}$. The duration of exposure was $600 \mathrm{~s}$.

\section{Electrochemical properties}

The electrochemical reactivities of the o-LiMnO${ }_{2}$, LMO (5 GPa), LMO (8 GPa), and LMO (12 GPa) samples were examined with sandwich-type two-electrode cells. The powdered sample, acetylene black (AB, Denka Co., Ltd.), and polytetrafluoroethylene (PTFE, Daikin Industries Ltd.) were combined in a ratio of $70: 20: 10$ to give a viscoelastic mixture, which was then pressed onto an aluminum mesh current collector with a diameter of $16 \mathrm{~mm}$. The mixture functioned as a working electrode. Lithium metal pressed onto $19 \mathrm{~mm}$-wide stainless steel was used as a counter electrode. The electrolyte was made from a solution of $1 \mathrm{M} \mathrm{LiPF}_{6}$ dissolved in ethylene carbonate (EC)/dimethyl carbonate (DMC) at an EC : DMC ratio of $3: 7 \mathrm{v} / \mathrm{v}$ (Kishida Chemical Company Ltd.) and the separator was constructed from two sheets of porous polyethylene membrane
(Tonen-General Sekiyu K. K.). The cells were assembled in an argon-filled glove box and operated at a current density of 0.025 $\mathrm{mA} \mathrm{cm}{ }^{-2}$. The voltage ranged from 1.8 to $4.8 \mathrm{~V}$ and the operating temperature was set at 25 or $40{ }^{\circ} \mathrm{C}$.

After cycling test at $25^{\circ} \mathrm{C}$, crystal structures of the samples were investigated using synchrotron XRD and Raman measurements to clarify both macroscopic and microscopic structural changes during the cycling. The cells were charged and discharged twenty times at $25{ }^{\circ} \mathrm{C}$. The cycled samples were then taken from the working electrodes, which had been thoroughly rinsed with a diethyl carbonate solution. Each of the samples was packed into a capillary tube with a diameter of $0.7 \mathrm{~mm}$ and put into a quartz glass cell (GL Sciences Inc.) for the XRD measurements and for the Raman spectroscopy, respectively. All the procedures were conducted in the argon-filled glove box, so as not to contact with the atmosphere. The laser power of the Raman spectroscopy was set at $1.0 \mathrm{~mW}$ in consideration of absorbance of the quartz cell. The Raman spectra of the charged LMO (12 GPa) sample, $\mathrm{LiMn}_{2} \mathrm{O}_{4}$, PTFE, and $\mathrm{AB}$ were also measured.

\section{Results and discussion}

\section{Morphological and structural characterization}

Fig. 2a-d show SEM images for the o-LiMnO LMO (8 GPa), and LMO (12 GPa) samples, respectively. Particles of o-LiMnO ${ }_{2}$ exhibit flake-like shapes with widths between 2-10 $\mu \mathrm{m}$ and thicknesses less than $2 \mu \mathrm{m}$. The particle shapes appear to round out and become uniform in size with increasing applied pressure, i.e., rough shapes with a dispersive size of 1$10 \mu \mathrm{m}$ at $5 \mathrm{GPa}$ and smooth morphologies with a dominant size of $\sim 8 \mu \mathrm{m}$ at $8 \mathrm{GPa}$ and $12 \mathrm{GPa}$ were observed. This morphological change is likely due to a phase transformation, as will be discussed below.

Fig. 3 shows the results of Rietveld analyses for the (a) o$\mathrm{LiMnO}_{2}$, (b) LMO (5 GPa), (c) LMO (8 GPa), and (d) LMO (12 $\mathrm{GPa}$ ) samples. The crystal structure of the o- $\mathrm{LiMnO}_{2}$ sample was 

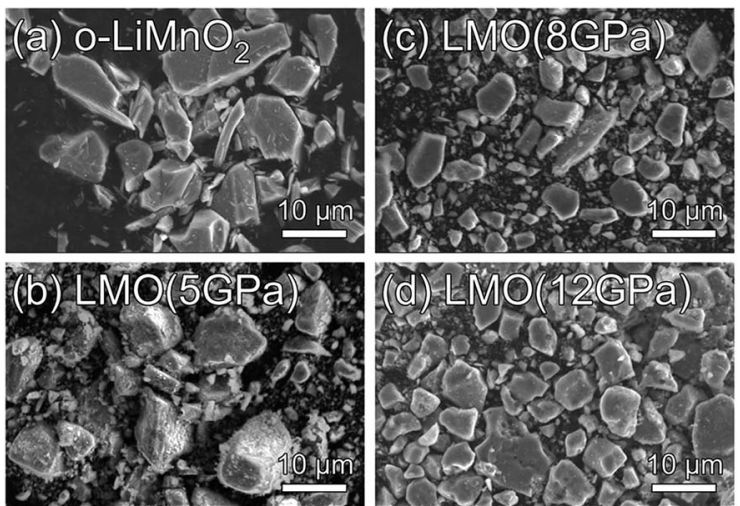

Fig. 2 SEM images for the (a) O-LiMnO , (b) LMO (5 GPa), (c) LMO (8 $\mathrm{GPa})$, and (d) LMO (12 GPa) samples.

assigned as an orthorhombic $\beta$ - $\mathrm{NaMnO}_{2}$-type structure with Pmmn space group; that is, a zigzag layered structure in which $\mathrm{Li}$ and $\mathrm{Mn}$ atoms occupy each of the octahedral $2 b$ sites (Fig. 1c). However, the o- $\mathrm{LiMnO}_{2}$ sample is not in a single phase but contained some impurity phases as shown by asterisk marks at around $2 \theta=10^{\circ}$ and $16^{\circ}$, and these were found to be hausmannite $\left(\mathrm{Mn}_{3} \mathrm{O}_{4}\right.$ with $\mathrm{I}_{1} /$ amd space group) and spinel $\mathrm{LiMn}_{2} \mathrm{O}_{4}$ by examining the possible crystal structures of LMOs and manganese oxides. Thus, we performed Rietveld analyses with three coexisting phases, in which a Mn under-stoichiometric $\mathrm{Li}_{1+\delta} \mathrm{Mn}_{1-\delta} \mathrm{O}_{2}$ is adopted to refine the crystal structure of $\mathrm{o}^{-}$ $\mathrm{LiMnO}_{2}$. Here, $\delta$ represents the Mn deficiency due to impurities. Moreover, we considered $\mathrm{Li}$ and $\mathrm{Mn}$ atoms to randomly occupy each of the $2 b$ sites, as a cation mixing of $\mathrm{Li}$ and transition metal ions occasionally occurs in lithium insertion materials. ${ }^{31}$ The structure parameters of the o- $\mathrm{LiMnO}_{2}$ sample are listed in Table 2. The lattice parameters of o- $\mathrm{LiMnO}_{2}$ were calculated to be $a_{\mathrm{o}}=$ $2.80700(2) \AA, b_{\mathrm{o}}=4.57721(2) \AA$, and $c_{\mathrm{o}}=5.75210(3) \AA$. The actual composition was determined to be $\mathrm{Li}_{1.005} \mathrm{Mn}_{0.995} \mathrm{O}_{2}(\delta=$ $0.005)$, where $1.5 \%$ of the Mn ions occupied $\mathrm{Li}(2 b)$ sites. The weight fractions were $98.9 \mathrm{wt} \%$ for $\mathrm{Li}_{1.005} \mathrm{Mn}_{0.995} \mathrm{O}_{2}, 0.7 \mathrm{wt} \%$ for $\mathrm{Mn}_{3} \mathrm{O}_{4}$, and $0.4 \mathrm{wt} \%$ for $\mathrm{LiMn}_{2} \mathrm{O}_{4}$, giving a $\mathrm{Li} / \mathrm{Mn}$ ratio of $0.999 /$ 1.000 , which was consistent with the $\mathrm{Li} / \mathrm{Mn}$ ratio of the starting material.

For the LMO (5 GPa) sample, the diffraction line at $2 \theta=12.8^{\circ}$ decreases, but the diffraction line at $2 \theta=12.3^{\circ}$ clearly generates, due to the formation of the $\mathrm{t}-\mathrm{LiMnO}_{2}$ phase (see the inset of Fig. 3b). As listed in Table $\mathrm{S} 1, \dagger$ the mass fractions of $\mathrm{o}^{-}$ $\mathrm{LiMnO}_{2}$ and $\mathrm{t}-\mathrm{LiMnO}_{2}$ were found to be 86.6 and $8.6 \mathrm{wt} \%$, respectively. For the LMO (8 GPa) and LMO $(12 \mathrm{GPa})$ samples,
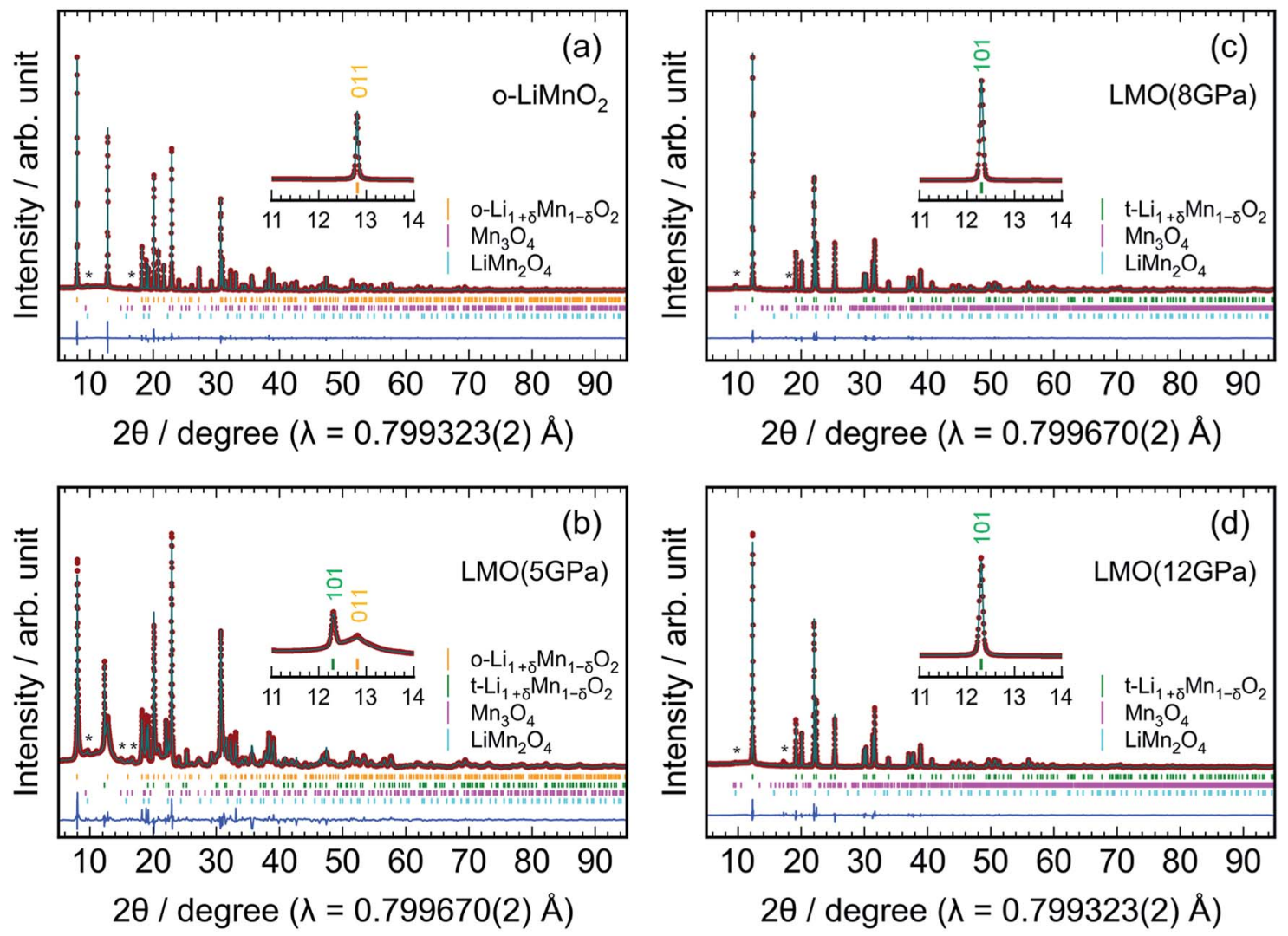

Fig. 3 Rietveld results for the (a) o- $\mathrm{LiMnO}_{2}$, (b) LMO (5 GPa), (c) LMO (8 GPa), and (d) LMO (12 GPa) samples. Enlarged patterns between $11^{\circ}$ and $14^{\circ}$ are also shown in the insets to clarify a phase transformation. The orange, green, magenta, and cyan vertical lines indicate the Bragg positions for orthorhombic $\mathrm{Li}_{1+\delta} \mathrm{Mn}_{1-\delta} \mathrm{O}_{2}$ with Pmmn space group, tetragonal $\mathrm{Li}_{1+\delta} \mathrm{Mn}_{1-\delta} \mathrm{O}_{2}$ with $14_{1} / \mathrm{amd}, \mathrm{Mn}_{3} \mathrm{O}_{4}$ with $/ 4_{1} / \mathrm{amd}$ or $\mathrm{Pbcm}$ space group, and $\mathrm{LiMn}_{2} \mathrm{O}_{4}$ with $\mathrm{Fd} \overline{3} \mathrm{~m}$ space group, respectively. The diffraction lines from the $\mathrm{Mn}_{3} \mathrm{O}_{4}$ and $\mathrm{LiMn}_{2} \mathrm{O}_{4}$ impurities are denoted by asterisks (*). Red dots and solid green lines indicate observed and calculated profiles, respectively, whereas solid blue lines show the differences between the observed and the calculated profiles. 
Table 2 Structure parameters of the o- $\mathrm{LiMnO}_{2}$ sample determined by Rietveld analyses

\begin{tabular}{|c|c|c|c|c|c|c|c|c|}
\hline Phase & Space group & Atom & Wyckoff position & $g^{a}$ & $x$ & $y$ & $z^{a}$ & $B^{a} / \AA^{2}$ \\
\hline \multirow[t]{5}{*}{ o-LiMnO } & Pmmn & Li1 & $2 b$ & $0.985(1)$ & $1 / 4$ & $3 / 4$ & $0.1188(9)$ & $1.32(8)$ \\
\hline & & Mn1 & $2 b$ & $0.015(1)$ & $1 / 4$ & $3 / 4$ & $0.1188(9)$ & $1.32(8)$ \\
\hline & & Li2 & $2 b$ & $0.020(1)$ & $1 / 4$ & $3 / 4$ & $0.6347(1)$ & $0.55(1)$ \\
\hline & & O1 & $2 a$ & 1 & $1 / 4$ & $1 / 4$ & $0.1432(3)$ & $0.58(2)$ \\
\hline & & $\mathrm{O} 2$ & $2 a$ & 1 & $1 / 4$ & $1 / 4$ & $0.6004(3)$ & $0.58(2)$ \\
\hline
\end{tabular}

Composition: $\mathrm{Li}_{1.005} \mathrm{Mn}_{0.995} \mathrm{O}_{2}(\delta=0.005), a_{\mathrm{o}}=2.80700(2) \AA, b_{\mathrm{o}}=4.57721(2) \AA$, and $c_{\mathrm{o}}=5.75210(3) \AA$

Reliable factors: $R_{\mathrm{wp}}=5.658 \%, R_{\mathrm{p}}=4.184 \%$, and $S=0.4501$

Mass fractions: $98.9 \mathrm{wt} \%$ for o- $\mathrm{LiMnO}_{2}, 0.7 \mathrm{wt} \%$ for $\mathrm{Mn}_{3} \mathrm{O}_{4}$, and $0.4 \mathrm{wt} \%$ for $\mathrm{LiMn}_{2} \mathrm{O}_{4}$

${ }^{a}$ Constraints: $g(\operatorname{Mn} 1)=1-g(\operatorname{Li1}), g(\operatorname{Mn} 2)=g(\operatorname{Li1})-\delta, g(\operatorname{Li} 2)=1+\delta-g(\operatorname{Li} 1), z(\operatorname{Mn} 1)=z(\operatorname{Li} 1), z(\operatorname{Li} 2)=z(\operatorname{Mn} 2), B(\operatorname{Mn} 1)=B(\operatorname{Li} 1), B(\operatorname{Li} 2)=B(\operatorname{Mn} 2)$, and $B(\mathrm{O} 2)=B(\mathrm{O} 1)$.

the diffraction line at $2 \theta=12.8^{\circ}$ disappears, and almost all diffraction lines can be assigned as the tetragonal $\gamma-\mathrm{LiFeO}_{2}$-type structure with $I 4_{1} /$ amd space group (Fig. $3 \mathrm{c}$ and d). The hausmannite impurity also transformed into a $\mathrm{CaMn}_{2} \mathrm{O}_{4}$-type structure $(\mathrm{Pbcm})$ with an applied pressure up to $8 \mathrm{GPa} \cdot{ }^{32}$ Table 3 shows the structure parameters of the LMO $(12 \mathrm{GPa})$ sample as determined by Rietveld analyses under identical assumptions as the o- $\mathrm{LiMnO}_{2}$ sample. The tetragonal lattice parameters, $a_{\mathrm{t}}$ and $c_{\mathrm{t}}$, were determined to be 4.18278(2) and 8.22922(6) $\AA$, respectively. Note that the actual composition of t- $\mathrm{LiMnO}_{2}$, $\mathrm{Li}_{1.012} \mathrm{Mn}_{0.988} \mathrm{O}_{2}(\delta=0.012)$, was almost identical to that of $\mathrm{o}-$ $\mathrm{LiMnO}_{2}$. From the occupancy factor, $g$, it was shown that $\mathrm{Mn}$ ions occupy $0.8 \%$ of the Li $(4 a)$ sites. As shown in Table S3, $\dagger$ there were no significant differences in the structural parameters, including the $a_{\mathrm{t}}, c_{\mathrm{t}}$, composition, atomic coordination, and $g$ between the LMO (8 GPa) and LMO (12 GPa) samples.

The change in the XRD patterns indicated that o- $\mathrm{LiMnO}_{2}$ gradually transformed into t-LiMnO${ }_{2}$ at $5 \mathrm{GPa}$, with the phase transformation occurring as the pressure reached $8 \mathrm{GPa}$. Conversely, Sugiyama et al. reported that this phase transformation was completed at a pressure of $5 \mathrm{GPa}$ in Mn overstoichiometric $\mathrm{Li}_{0.93} \mathrm{Mn}_{1.07} \mathrm{O}_{2} .{ }^{22}$ Therefore, the transformation from o- $\mathrm{LiMnO}_{2}$ to $\mathrm{t}-\mathrm{LiMnO}_{2}$ is very sensitive to the $\mathrm{Li} / \mathrm{Mn}$ ratio of o-LiMnO ${ }_{2} ; \mathrm{Mn}$ under-stoichiometric $\mathrm{Li}_{1.1} \mathrm{Mn}_{0.9} \mathrm{O}_{2}(\delta=0.1)$ actually transformed into a rock-salt structure rather than into $\mathrm{t}-\mathrm{LiMnO}_{2}$ at $5 \mathrm{GPa}$ and $1000{ }^{\circ} \mathrm{C} .{ }^{22}$

Fig. 4a-d show Raman spectra of the o-LiMnO ${ }_{2}$, LMO (5 GPa), LMO (8 GPa), and LMO (12 GPa) samples, respectively. Factor group analyses ${ }^{33}$ predicted twelve Raman bands of $4 A_{g}+$
$4 B_{2 \mathrm{~g}}+4 B_{3 \mathrm{~g}}$ for o-LiMnO $\mathrm{L}_{2}$ structure and eight Raman bands of $A_{1 \mathrm{~g}}+3 B_{1 \mathrm{~g}}+4 E_{\mathrm{g}}$ for t-LiMnO 2 structure. The Raman spectrum for the o- $\mathrm{LiMnO}_{2}$ sample shows three major Raman bands at 411, 556, and $657 \mathrm{~cm}^{-1}$ and three minor Raman bands at 191, 363, and $488 \mathrm{~cm}^{-1}$. Although all of the Raman bands are not fully assigned, according to the previous reports, ${ }^{34-36}$ the major Raman bands are attributed to vibrations in the $\mathrm{MnO}_{6}$ octahedra, that is, the O-Mn-O stretching modes at $657 \mathrm{~cm}^{-1}$, the $\mathrm{O}-\mathrm{Mn}-\mathrm{O}$ bending modes at $556 \mathrm{~cm}^{-1}$, and the $\mathrm{Mn}-\mathrm{O}-\mathrm{Mn}$ deformation modes at $441 \mathrm{~cm}^{-1}$. The Raman spectrum of the LMO (5 GPa) sample is similar with that of the o- $\mathrm{LiMnO}_{2}$ sample, however, the intensities of the Raman bands at $\sim 411$, 556 , and $657 \mathrm{~cm}^{-1}$ become weak compared with its original Raman spectrum. Furthermore, new and weak Raman bands are observed at 406, 510, and $617 \mathrm{~cm}^{-1}$, and these Raman bands are clearly observed in the Raman spectra of the LMO (8 GPa) and LMO (12 GPa) samples. There are at least ten Raman bands in the Raman spectrum of the LMO (12 GPa) sample, although the theoretical calculation predicted eight Raman bands. This difference is probably due to the nonstoichiometry and/or impurity phases in the LMO (12 GPa) sample. Anyway Raman spectroscopy clarified that the transformation from o- $\mathrm{LiMnO}_{2}$ to $\mathrm{t}$-LiMnO $\mathrm{H}_{2}$ is achieved under pressures above $8 \mathrm{GPa}$, which is consistent with the results of the XRD measurements.

\section{Electrochemical properties}

Fig. 5a shows charge and discharge curves of the Li cell with the $\mathrm{LiMnO}_{2}$ sample, operated at temperature of $25{ }^{\circ} \mathrm{C}$. The cell voltage $(E)$ increases rapidly from an open circuit voltage $(\sim 3.1$

Table 3 Structure parameters of the LMO (12 GPa) sample determined by Rietveld analyses

\begin{tabular}{|c|c|c|c|c|c|c|c|c|}
\hline Phase & Space group & Atom & Wyckoff position & $g^{a}$ & $x$ & $y$ & $z$ & $B^{a} / \AA^{2}$ \\
\hline \multirow[t]{4}{*}{$\mathrm{t}-\mathrm{LiMnO}_{2}$} & $I 4_{1} /$ amd & Li1 & $4 a$ & $0.992(1)$ & 0 & $3 / 4$ & $1 / 8$ & $1.31(9)$ \\
\hline & & Mn1 & $4 a$ & $0.008(1)$ & 0 & $3 / 4$ & $1 / 8$ & $1.31(9)$ \\
\hline & & Li2 & $4 b$ & $0.020(1)$ & 0 & $1 / 4$ & $3 / 8$ & $0.51(1)$ \\
\hline & & O1 & $8 e$ & 1 & 0 & $1 / 4$ & $0.1413(1)$ & $1.2(2)$ \\
\hline
\end{tabular}

Composition: $\mathrm{Li}_{1.012} \mathrm{Mn}_{0.988} \mathrm{O}_{2}(\delta=0.012), a_{\mathrm{t}}=4.18278(2) \AA$, and $c_{\mathrm{t}}=8.22922(6) \AA$

Reliable factors: $R_{\mathrm{wp}}=6.403 \%, R_{\mathrm{p}}=4.544 \%$, and $S=0.4712$

Mass fractions: $97.8 \mathrm{wt} \%$ for $\mathrm{t}-\mathrm{LiMnO}_{2}, 1.8 \mathrm{wt} \%$ for $\mathrm{Mn}_{3} \mathrm{O}_{4}$, and $0.4 \mathrm{wt} \%$ for $\mathrm{LiMn}_{2} \mathrm{O}_{4}$

${ }^{a}$ Constraints: $g(\operatorname{Mn} 1)=1-g(\operatorname{Li} 1), g(\operatorname{Mn} 2)=g(\operatorname{Li} 1)-\delta, g(\operatorname{Li} 2)=1+\delta-g(\operatorname{Li} 1), B(\operatorname{Mn} 1)=B(\operatorname{Li} 1)$, and $B(\operatorname{Li} 2)=B(\operatorname{Mn} 2)$. 


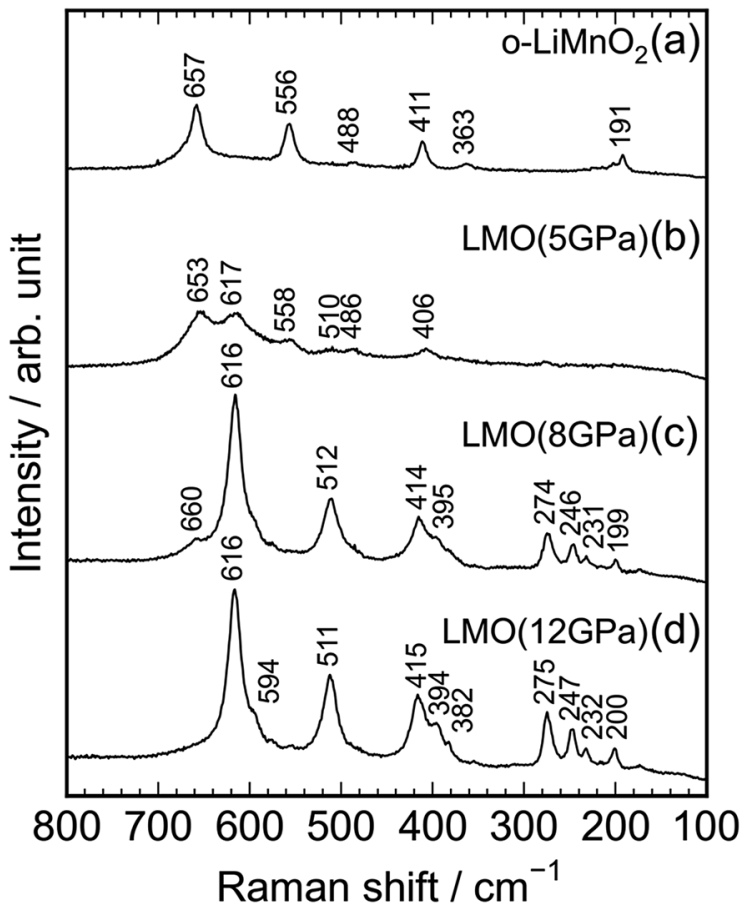

Fig. 4 Raman spectra of the (a) O- $\mathrm{LiMnO}_{2}$, (b) LMO (5 GPa), (c) LMO (8 $\mathrm{GPa})$, and (d) LMO (12 GPa) samples.

V) before plateauing at $\sim 3.5 \mathrm{~V}$ when the $Q_{\text {cha }}$ reaches $120 \mathrm{~mA} \mathrm{~h} \mathrm{~g}^{-1}$. Then, the $E$ climbs to $4.8 \mathrm{~V}$ with a gentle gradient during the initial charge. In the discharge curve, however, the $E$ drops sharply to $3.5 \mathrm{~V}$, and gradually decreases to $\sim 3.0 \mathrm{~V}$ without any clear voltage plateaus. The $Q_{\text {cha }}$ is $160 \mathrm{~mA} \mathrm{~h} \mathrm{~g}^{-1}$, whereas discharge capacity $\left(Q_{\text {dis }}\right)$ is only $70 \mathrm{~mA} \mathrm{~h} \mathrm{~g}^{-1}$. New voltage plateaus appeared at $\sim 3.0$ and $4.0 \mathrm{~V}$ in subsequent charge and discharge curves. The differences in charge and discharge curves between $1^{\text {st }}$ and subsequent cycles is caused by an irreversible structural transformation to the $\mathrm{Li}_{x} \mathrm{Mn}_{2} \mathrm{O}_{4}$ spinel during the initial cycle, as previously reported. ${ }^{\mathbf{1 2 , 1 8 , 3 7}}$

Fig. 5b-d display the charge and discharge curves of the lithium cells with the LMO (5 GPa), LMO (8 GPa), and LMO (12 GPa) samples, respectively. The charge and discharge curves of these three samples are clearly different from those of $\mathrm{o}$ $\mathrm{LiMnO}_{2}$; i.e., the $E$ monotonically increases from $3.2 \mathrm{~V}$ to $4.8 \mathrm{~V}$ without any apparent voltage plateaus. The $Q_{\text {cha }}$ of LMO (5 GPa) is $154 \mathrm{~mA} \mathrm{~h} \mathrm{~g}^{-1}$, while the $Q_{\text {cha }}$ values of LMO (8 GPa) and LMO (12 $\mathrm{GPa}$ ) are 41 and $37 \mathrm{~mA} \mathrm{~h} \mathrm{~g}{ }^{-1}$, respectively, which are approximately $13 \%$ of the $Q_{\text {theo }}$. The initial discharge curves have a similar $E$ profile with a broad center at $\sim 3.0 \mathrm{~V}$. The $Q_{\text {dis }}$ values of the LMO (5 GPa), LMO (8 GPa), and LMO (12 GPa) samples are 52,21 , and $22 \mathrm{~mA} \mathrm{~h} \mathrm{~g}^{-1}$, respectively. Besides the decline in the $E$, as similarly noted for o- $\mathrm{LiMnO}_{2}$, both the charge and discharge curves display multiple voltage plateaus with an increasing cycle number. This implied that t-LiMnO irreversibly transformed into the $\mathrm{Li}_{x} \mathrm{Mn}_{2} \mathrm{O}_{4}$ spinel with the electrochemical cycling. The cycle performances of these four samples are given in Fig. S1. $\dagger$ The $Q_{\text {cha }}$ and $Q_{\text {dis }}$ values of o$\mathrm{LiMnO}_{2}[\mathrm{LMO}(5 \mathrm{GPa})]$ increase with the cycle numbers until tenth cycles, and then maintain at $\sim 150(100) \mathrm{mA} \mathrm{h} \mathrm{g}^{-1}$. On the

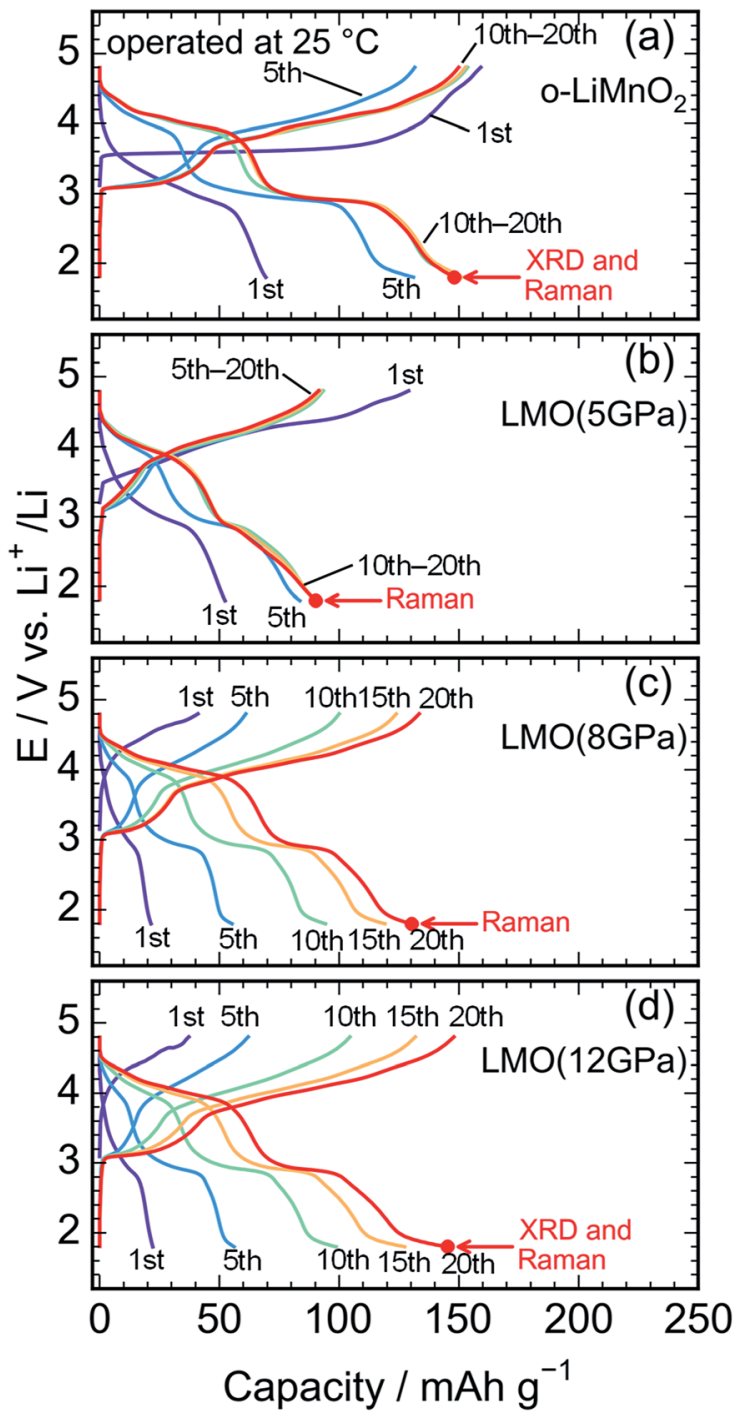

Fig. 5 Charge and discharge curves of the lithium cells with the (a) O$\mathrm{LiMnO}_{2}$, (b) LMO (5 GPa), (c) LMO (8 GPa), and (d) LMO (12 GPa) samples. The cells were operated at temperature of $25^{\circ} \mathrm{C}$. Ex situ XRD measurements and Raman spectroscopy were conducted at the discharged state, as indicated by the red arrows.

other hand, the $Q_{\text {cha }}$ and $Q_{\text {dis }}$ values of LMO (8 GPa) and LMO $(12 \mathrm{GPa})$ increase with the cycle numbers up to twenty cycles. The $Q_{\text {cha }}$ and $Q_{\text {dis }}$ values of LMO $(12 \mathrm{GPa})$ are similar with those of o-LiMnO${ }_{2}$.

Fig. 6a and $\mathrm{b}$ show charge and discharge curves of the lithium cells with the o- $\mathrm{LiMnO}_{2}$ and LMO (12 GPa) samples, respectively, operated at temperature of $40^{\circ} \mathrm{C}$. The initial $Q_{\text {cha }}$ of $\mathrm{o}-\mathrm{LiMnO}_{2}$ is approximately $200 \mathrm{~mA} \mathrm{~h} \mathrm{~g}{ }^{-1}$, which is larger than the value $\left(=160 \mathrm{~mA} \mathrm{~h} \mathrm{~g}{ }^{-1}\right)$ obtained at $25{ }^{\circ} \mathrm{C}$. This originates from the appearance of a moderate voltage plateau over $4.0 \mathrm{~V}$ with a $Q_{\text {cha }}$ of $\sim 50 \mathrm{~mA} \mathrm{~h} \mathrm{~g}^{-1}$, as reported for an o- $\mathrm{LiMnO}_{2} / \mathrm{Li}$ cell at $55{ }^{\circ} \mathrm{C}$ by Cho. ${ }^{38}$ Subsequent charge and discharge curves reveal the increases in $Q_{\text {cha }}$ from $200 \mathrm{~mA} \mathrm{~h} \mathrm{~g}^{-1}$ to $225 \mathrm{~mA} \mathrm{~h} \mathrm{~g}^{-1}$ and in $Q_{\text {dis }}$ from $155 \mathrm{~mA} \mathrm{~h} \mathrm{~g}^{-1}$ to $220 \mathrm{~mA} \mathrm{~h} \mathrm{~g}^{-1}$. The irreversible transformation into the $\mathrm{Li}_{x} \mathrm{Mn}_{2} \mathrm{O}_{4}$ spinel is thought to be accelerated, compared to the measurements at $25{ }^{\circ} \mathrm{C}$. 


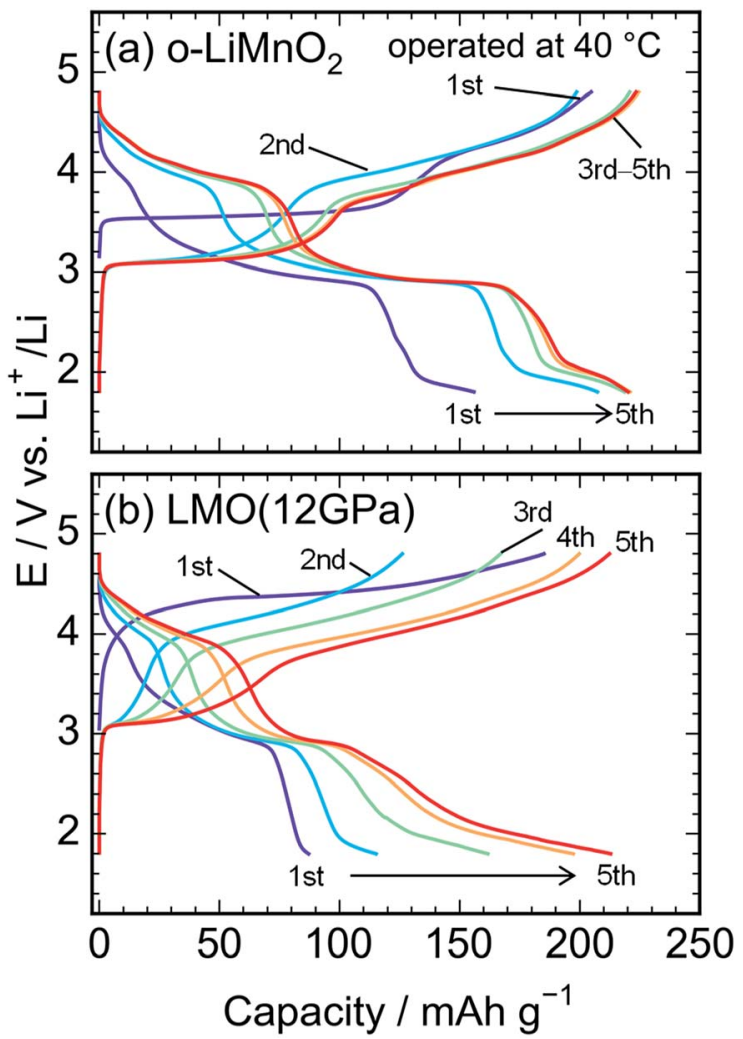

Fig. 6 Charge and discharge curves of the lithium cells with the (a) O$\mathrm{LiMnO}_{2}$ and (b) LMO (12 GPa) samples. The cells were operated at temperature of $40^{\circ} \mathrm{C}$.

The $E$ of LMO (12 GPa) slowly increases from an open circuit voltage of approximately $3.0 \mathrm{~V}$ to $\sim 4.4 \mathrm{~V}$ with a $Q_{\text {cha }}$ of $\sim 40 \mathrm{~mA} \mathrm{~h} \mathrm{~g}{ }^{-1}$ during the initial charge. Afterwards, the $E$ remains flat until finally reaching the cut-off voltage of $4.8 \mathrm{~V}$. In contrast to the situation observed at $25{ }^{\circ} \mathrm{C}$, the $Q_{\text {cha }}$ increases dramatically to $185 \mathrm{~mA} \mathrm{~h} \mathrm{~g}^{-1}$, in comparison to the $Q_{\text {theo }}$ of $65 \%$. The redox reaction at approximately $4.4 \mathrm{~V}$ is not observed in LMO ( $5 \mathrm{GPa})$, whereas it is clearly seen in the LMO (8 GPa) (see Fig. S2a and $\mathrm{b} \dagger$ ). According to the first-principle calculations and numerical simulations reported by Ceder's group, ${ }^{39-42}$ the $\mathrm{Li}^{+}$ion diffusion barrier for $\gamma$ - $\mathrm{LiFeO}_{2}$-type structured materials is higher than that for other positive electrode materials such as $\mathrm{LiCoO}_{2}$ with an $\alpha-\mathrm{NaFeO}_{2}$-type structure and $\mathrm{LiMn}_{2} \mathrm{O}_{4}$ with a spinel-type structure. Moreover, the $\mathrm{Mn}$ ions that occupied $0.8 \%$ of the $4 a$ lithium sites (Table 3 ) would block the lithium diffusion path at $25{ }^{\circ} \mathrm{C}$, as reported for $\mathrm{LiFePO}_{4}$, which has a one-dimensional lithium ion path along the $b$ axis. $^{43}$ Therefore, by increasing the temperature up to $40{ }^{\circ} \mathrm{C}, \mathrm{Li}^{+}$ions could be kinetically removed from the lattice during the initial charge reaction. Moreover, the initial charge curve exhibited an $E_{\text {ave }}$ of $4.56 \mathrm{~V}$, indicating that the $\mathrm{Mn}^{3+} / \mathrm{Mn}^{4+}$ redox potential in $\mathrm{t}-\mathrm{LiMnO}_{2}$ was superior to that of o- $\mathrm{LiMnO}_{2}\left(E_{\text {ave }}=3.86 \mathrm{~V}\right)$. Since the $W$ for positive electrode materials is calculated as a product of the $Q_{\text {recha }}$ and $E_{\text {ave }}$, the $W$ for t-LiMnO${ }_{2}$ during the initial charge was estimated to be $844 \mathrm{~mW} \mathrm{~h} \mathrm{~g}{ }^{-1}$ using a $Q_{\text {cha }}=$ $185 \mathrm{~mA} \mathrm{~h} \mathrm{~g}^{-1}$ and $E_{\text {ave }}=4.56 \mathrm{~V}$. This value was much larger than the $W$ for $\mathrm{LiMn}_{2} \mathrm{O}_{4}\left(\sim 500 \mathrm{~mW} \mathrm{~h} \mathrm{~g} \mathrm{~g}^{-1}\right)$ which is already commercially available as the positive electrode material. ${ }^{8} \mathrm{~A}$ high $E_{\text {ave }}$ is favorable for the potential application of $\mathrm{t}-\mathrm{LiMnO}_{2}$ in this field.

The initial discharge curve, by contrast, could not maintain this $E_{\text {ave }}$ and exhibited a $Q_{\text {dis }}$ of $87 \mathrm{~mA} \mathrm{~h}^{-1}$, resulting in a $W$ value of $273 \mathrm{~mW} \mathrm{~h} \mathrm{~g}^{-1}$. This was due to the type of polarization, which was similar to that seen in the results obtained at $25{ }^{\circ} \mathrm{C}$. With an increasing cycle number, the $Q_{\text {cha }}$ and $Q_{\text {dis }}$ improved to approximately $210 \mathrm{~mA} \mathrm{~h} \mathrm{~g}^{-1}$. Nevertheless, the $E_{\text {ave }}$ was about $2.9 \mathrm{~V}$ at discharge and $4.0 \mathrm{~V}$ at charge over the course of more than two cycles. The $W$ in the charge and discharge curves during the fifth cycle was $815 \mathrm{~mW} \mathrm{~h} \mathrm{~g}^{-1}$ and $618 \mathrm{~mW} \mathrm{~h} \mathrm{~g}^{-1}$, respectively.

\section{Crystal structure change upon electrochemical cycling}

Ex situ XRD measurements and Raman spectroscopy were conducted on the cycled electrodes to understand the phase transformation of $\mathrm{t}-\mathrm{LiMnO}_{2}$ during cycling. The XRD patterns of the cycled o-LiMnO 2 and LMO (12 GPa) samples are shown in Fig. 7a and b, respectively. The XRD pattern of $\mathrm{o}-\mathrm{LiMnO}_{2}$ is assigned as a mixture of the $\mathrm{Li}_{x} \mathrm{Mn}_{2} \mathrm{O}_{4}$ spinel $(F d \overline{3} m)$ with $x<1$, lithiated $\mathrm{Li}_{y} \mathrm{Mn}_{2} \mathrm{O}_{4}$ tetragonal ( I $_{1} /$ amd) phase with $y>1$, and PTFE originated from the binder in the electrode. The lattice parameters, which were calculated using the least squares method with more than five non-overlapping diffraction lines, are found to be $a_{\mathrm{c}}=8.224(9) \AA$ for $\mathrm{Li}_{x} \mathrm{Mn}_{2} \mathrm{O}_{4}$, and $a_{\mathrm{t}}=5.666(6) \AA$ and $c_{\mathrm{t}}=9.151(9) \AA$ for $\mathrm{Li}_{y} \mathrm{Mn}_{2} \mathrm{O}_{4}$. Since these lattice parameters correspond to those for $\mathrm{Li}_{0.98} \mathrm{Mn}_{2} \mathrm{O}_{4}\left(a_{\mathrm{c}}=8.230 \AA\right)$ and $\mathrm{Li}_{1.82} \mathrm{Mn}_{2} \mathrm{O}_{4}\left(a_{\mathrm{t}}=5.654 \AA\right.$ and $\left.c_{\mathrm{t}}=9.202 \AA\right),{ }^{44}$ the $x$ and $y$ values are estimated to be 0.98 and 1.82 , respectively.

As seen in Fig. 7b, the XRD pattern of the cycled LMO (12 GPa) sample is assigned as a mixture of the $\mathrm{Li}_{x} \mathrm{Mn}_{2} \mathrm{O}_{4}$ spinel, the $\mathrm{Li}_{y} \mathrm{Mn}_{2} \mathrm{O}_{4}$ tetragonal, $\mathrm{t}-\mathrm{Li}_{z} \mathrm{MnO}_{2}$, and PTFE. The evolution of the $\mathrm{Li}_{x} \mathrm{Mn}_{2} \mathrm{O}_{4}$ spinel and $\mathrm{Li}_{y} \mathrm{Mn}_{2} \mathrm{O}_{4}$ tetragonal phases confirms the transformation to the spinel structure from t-LiMnO $\mathrm{O}_{2}$ during cycling, as in the case for o- $\mathrm{LiMnO}_{2}$. The lattice parameters were calculated to be $a_{\mathrm{c}}=8.252(4) \AA$ for $\mathrm{Li}_{x} \mathrm{Mn}_{2} \mathrm{O}_{4}, a_{\mathrm{t}}=5.657(4) \AA$ and $c_{\mathrm{t}}=9.173(7) \AA$ for $\mathrm{Li}_{y} \mathrm{Mn}_{2} \mathrm{O}_{4}$, and $a_{\mathrm{t}}=4.1854(8) \AA$ and $c_{\mathrm{t}}=$ $8.230(2) \AA$ for $\mathrm{t}-\mathrm{Li}_{z} \mathrm{MnO}_{2}$. Thus, the $x, y$, and $z$ values were estimated to be $0.98,1.82$, and $\sim 1$, respectively.

As seen in Fig. S3, $\dagger$ the Raman spectrum of the charged LMO (12 GPa) sample is similar with that of the pristine LMO (12 GPa) sample, except for the Raman band at $654 \mathrm{~cm}^{-1}$. This indicates that the local structure of LMO $(12 \mathrm{GPa})$ is maintained during the initial charge reaction. However, Fig. 8 clarifies that the extended twenty cycle test converts the $\mathrm{t}-\mathrm{LiMnO}_{2}$ structure into the spinel structure. That is, there are only three broad Raman bands at $\sim 650,620$, and $490 \mathrm{~cm}^{-1}$ in the cycled $\mathrm{o}^{-}$ $\mathrm{LiMnO}_{2}$ and LMO (12 GPa) samples, and these Raman spectra are similar with the Raman spectrum of the pristine $\mathrm{LiMn}_{2} \mathrm{O}_{4}$ sample. The Raman bands at $\sim 650,620$, and $490 \mathrm{~cm}^{-1}$ are also observed in the cycled LMO (5 GPa) and LMO (8 GPa) samples (see Fig. $\mathrm{S} 4 \dagger$ ). It should be noted that the Raman spectra of the cycled (or charged) o-LiMnO 2 , LMO (5 GPa), LMO (8 GPa), and LMO (12 GPa) samples contain contributions of PTFE and AB, which were used for preparing the working electrodes. As seen 


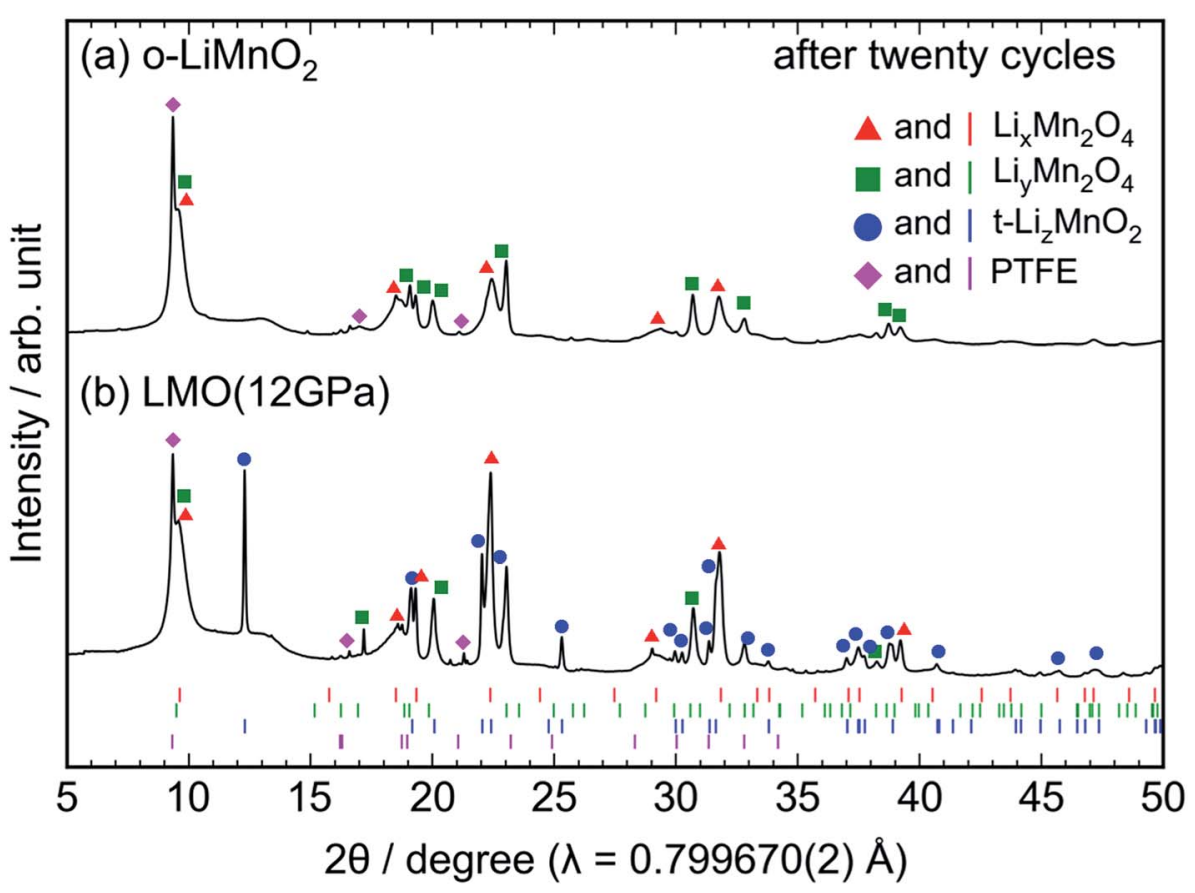

Fig. 7 Ex situ XRD patterns of the cycled (a) o- $\mathrm{LiMnO}_{2}$ and (b) LMO (12 GPa) samples. The measurements were performed at the discharged states, as indicated by the red arrows in Fig. $5 \mathrm{a}$ and d. Diffraction lines represented by red triangles, green squares, blue circles, and magenta diamonds, originate from those from $\mathrm{Li}_{x} \mathrm{Mn}_{2} \mathrm{O}_{4}$ with the spinel structure, $\mathrm{Li}_{y} \mathrm{Mn}_{2} \mathrm{O}_{4}$ with tetragonal structure, $\mathrm{t}-\mathrm{Li}_{z} \mathrm{MnO}_{2}$, and PTFE, respectively. The Bragg positions for each of these phases are also shown in the bottom using identically colored vertical lines.

in Fig. $\mathrm{S} 5, \dagger$ the Raman spectrum of PTFE shows three major Raman bands at 733,385 , and $290 \mathrm{~cm}^{-1}$, while that of $\mathrm{AB}$ is featureless. The contributions of PTFE and $\mathrm{AB}$ are, hence, negligibly small to the Raman spectra of the cycled (or charged) LMO samples.

Fig. 9 shows possible mechanisms of the transformation into the spinel structure from the delithiated (a) o- $\mathrm{LiMnO}_{2}$ and

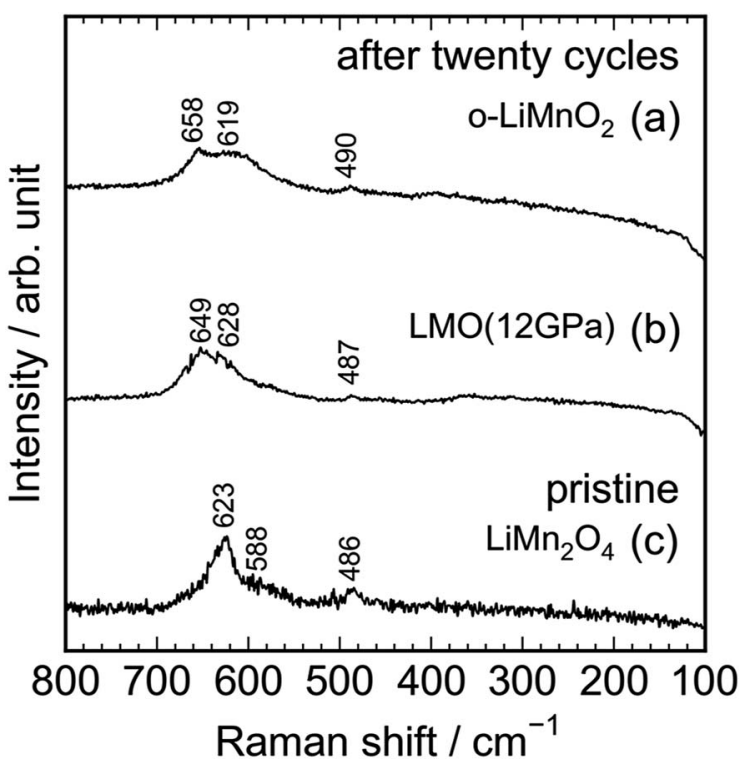

Fig. 8 Ex situ Raman spectra of the cycled (a) O- $\mathrm{LiMnO}_{2}$ and (b) $\mathrm{LMO}$ (12 $\mathrm{GPa}$ ) samples together with the Raman spectrum of the pristine (c) $\mathrm{LiMn}_{2} \mathrm{O}_{4}$. Raman spectra of (a) and (b) were taken at the discharged state, as indicated by the red arrows in Fig. $5 a$ and $d$. (b) $\mathrm{t}-\mathrm{LiMnO}_{2}$. Oxide ions in o-LiMnO $2, \mathrm{t}-\mathrm{LiMnO}_{2}$, and $\mathrm{Li}_{x} \mathrm{Mn}_{2} \mathrm{O}_{4}$ spinel are arranged in the same $\mathrm{ABCABC}$ stacking manner along the [012] direction for o-LiMnO ${ }_{2}$, [112] for t-LiMnO ${ }_{2}$, and [111] for $\mathrm{Li}_{x} \mathrm{Mn}_{2} \mathrm{O}_{4}$, although the orderings between $\mathrm{Mn}$ and vacancy (or Li) octahedral sites are different each other. According to Thackeray et al. ${ }^{15} \mathrm{Li}_{x} \mathrm{Mn}_{2} \mathrm{O}_{4}$ is formed from two repeating types of $\mathrm{MnO}_{2}$ sheets, as shown in the left and right sides of Fig. 9. Thus, there are two ways for the transformation into the spinel from $\mathrm{o}-\mathrm{LiMnO}_{2}$ or $\mathrm{t}-\mathrm{LiMnO}_{2}$. In the case of $\mathrm{o}-\mathrm{LiMnO}_{2}$, the transformation is caused by the displacement of half of the $\mathrm{Mn}$ ions to adjacent vacant octahedral sites. ${ }^{15-17}$ By contrast, the transformation of $\mathrm{t}-\mathrm{LiMnO}_{2}$ is achieved by the displacement of a quarter of the $\mathrm{Mn}$ ions in the $4 b$ sites into the vacant octahedral sites (4a) via adjacent octahedral sites without a rearrangement of the $\mathrm{ABCABC}$ oxygen packing (Fig. 9b). In this transformation, $\mathrm{t}-\mathrm{LiMnO}_{2}$ has $50 \%$ lower amounts of migrated Mn ions, resulting in approximately twice longer in routes of $\mathrm{Mn}$ ions, compared to the case for o- $\mathrm{LiMnO}_{2}$.

The transformation mechanism of $\mathrm{t}-\mathrm{LiMnO}_{2}$ shows that a suppression of the Mn displacement at the charged state is essential for realizing electrochemical properties such as the $Q_{\text {recha }}, E_{\text {ave }}$, and $W$ in the initial charge state over several cycles. Although the blocking effect of the movement of Mn ions in o$\mathrm{LiMnO}_{2}$ has not been reported for the substitution of different cations with Li ions, a small amount of doping could be suitable for t-LiMnO ${ }_{2}$ due to the small amount of migrated $\mathrm{Mn}$ ions and their long displacement distance. Recently, electrochemical properties of tetragonal structured $\mathrm{Li}_{0.35} \mathrm{MnO}_{2}$ (ref. 45) and $\mathrm{Li}_{0.59} \mathrm{MnO}_{2}$ (ref. 46) nanoparticles were reported; i.e., the initial $Q_{\text {cha }}$ and $Q_{\text {dis }}$ values of the nanosized $\mathrm{Li}_{0.35} \mathrm{MnO}_{2}$ are 72.9 and 
(a)

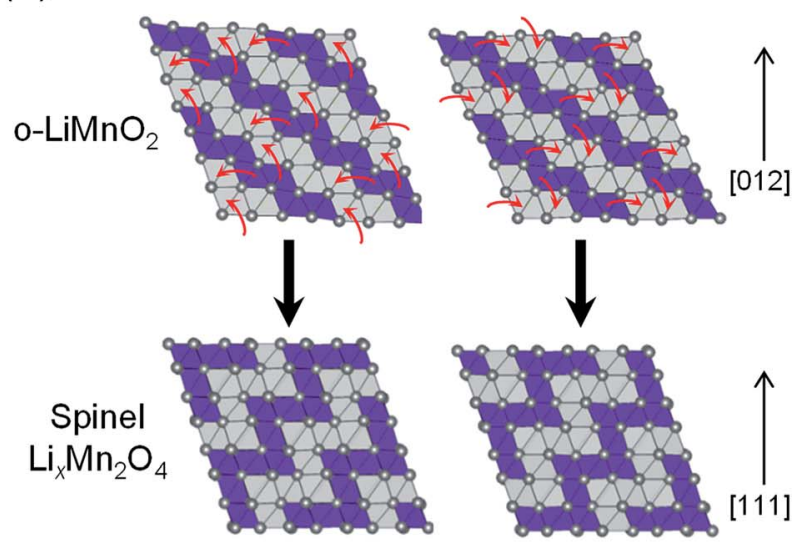

(b)
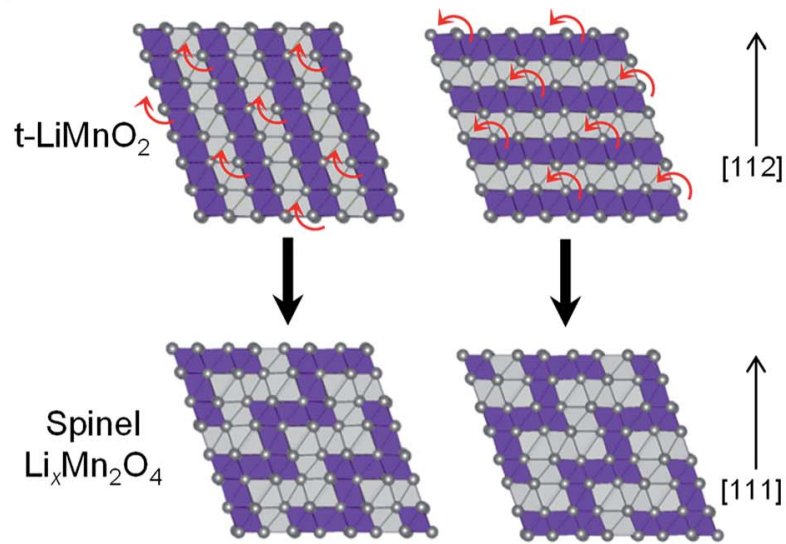

Fig. 9 Schematics of the transformations into $\mathrm{Li}_{x} \mathrm{Mn}_{2} \mathrm{O}_{4}$ spinel: (a) from o- $\mathrm{LiMnO}_{2}$ and (b) from $\mathrm{t}-\mathrm{LiMnO}_{2}$. The [012] in o- $\mathrm{LiMnO}_{2}$, [112] in t- $\mathrm{LiMnO}_{2}$, and [111] in $\mathrm{Li}_{x} \mathrm{Mn}_{2} \mathrm{O}_{4}$ directions correspond to those for oxygen closed-packing array. Purple and gray polyhedra are $\mathrm{MnO}_{6}$ and $\mathrm{LiO}_{6}$ (or $\mathrm{O}_{6}$ : is vacancy) octahedra, respectively. Red arrows represent the $\mathrm{Mn}$ migration paths to vacant sites.

$178.8 \mathrm{~mA} \mathrm{~h} \mathrm{~g}{ }^{-1}$, respectively. The $E$ profile is similar to the discharge curve of the $\mathrm{Li}_{x} \mathrm{Mn}_{2} \mathrm{O}_{4}$ spinel, although the crystal structure of $\mathrm{Li}_{0.35} \mathrm{MnO}_{2}$ is maintained even after twenty cycles. ${ }^{45}$ Since the electrochemical properties and structural stabilities of $\mathrm{t}-\mathrm{LiMnO}_{2}$ differ from those of $\mathrm{Li}_{0.35} \mathrm{MnO}_{2}$ (ref. 45) (or $\left.\mathrm{Li}_{0.59} \mathrm{MnO}_{2}\right),{ }^{47}$ both $\mathrm{Li}$ content $(x)$ and particle size also play important roles in stabilizing structure during cycling.

\section{Conclusions}

We first investigated the electrochemical performances of t$\mathrm{LiMnO}_{2}$ to obtain structural and electrochemical information regarding a series of $\mathrm{LiMnO}_{2}$ compounds with potential for the development of LMOs with high $W$. The t-LiMnO ${ }_{2}$ samples with $\gamma$-LiFeO ${ }_{2}$-type structure $\left(I_{1} /\right.$ amd $)$ were prepared from o-LiMnO under pressures up to $8 \mathrm{GPa}$ and at a temperature of $1000^{\circ} \mathrm{C}$, as evident by XRD measurements and Raman spectroscopy. Rietveld analyses indicated that the actual composition of $\mathrm{t}-\mathrm{LiMnO}_{2}$ is $\mathrm{Li}_{1.012} \mathrm{Mn}_{0.988} \mathrm{O}_{2}$, in which $\mathrm{Mn}$ ions partially occupy the $4 a$ lithium sites. The $Q_{\text {cha }}$ of t-LiMnO 2 rose to $185 \mathrm{~mA} \mathrm{~h} \mathrm{~g}^{-1}$ at $40{ }^{\circ} \mathrm{C}$ during the initial charge, even though it was only $37 \mathrm{~mA} \mathrm{~h} \mathrm{~g}^{-1}$ at $25{ }^{\circ} \mathrm{C}$. Furthermore, the initial charge curve showed that the $E_{\text {ave }}$ (4.56 V) with $\mathrm{Mn}^{3+} / \mathrm{Mn}^{4+}$ redox was the highest among LMOs such as o- $\mathrm{LiMnO}_{2}$ and $\mathrm{LiMn}_{2} \mathrm{O}_{4}$. However, the initial discharge curve did not maintain the $E_{\text {ave }}$, and exhibited a $Q_{\text {dis }}$ of $87 \mathrm{~mA} \mathrm{~h} \mathrm{~g}^{-1}$ due to an irreversible phase transformation into the $\mathrm{Li}_{x} \mathrm{Mn}_{2} \mathrm{O}_{4}$ spinel during the initial charge. Substitution of different cations and optimization of $\mathrm{Li}$ content and particle size will be necessary to maintain the electrochemical properties of t-LiMnO${ }_{2}$ throughout long cycles.

\section{Conflicts of interest}

There are no conflicts to declare.

\section{Acknowledgements}

We appreciate Dr Yuichi Kato of TCRDL for help with Raman spectroscopy. The XRD measurements were conducted on the BL5S2 beamline of the Aichi Synchrotron Radiation Center, Aichi Science \& Technology Foundation, Japan (Proposal No. 201702017 and No. 201706077).

\section{Notes and references}

1 M. M. Thackeray, W. I. F. David, P. G. Bruce and J. B. Goodenough, Mater. Res. Bull., 1983, 18, 461.

2 M. M. Thackeray, P. J. Johnson, L. A. de Picciotto, P. G. Bruce and J. B. Goodenough, Mater. Res. Bull., 1984, 19, 179.

3 M. M. Thackeray, S. H. Kang, C. S. Johnson, J. T. Vaughey, R. Benedek and S. A. Hackney, J. Mater. Chem., 2007, 17, 3053.

4 A. R. Armstrong and P. G. Bruce, Nature, 1996, 381, 499.

5 K. Yamaura, Q. Huang, L. Zhang, K. Takada, Y. Baba, T. Nagai, Y. Matsui, K. Kosuda and E. T. Muromachi, J. Am. Chem. Soc., 2006, 128, 9448.

6 M. Freire, N. V. Kosova, C. Jordy, D. Chateigner, O. I. Lebedev, A. Maignan and V. Pralong, Nat. Mater., 2016, 15, 173.

7 O. K. Park, Y. Cho, S. Lee, H.-C. Yoo, H.-K. Song and J. Cho, Energy Environ. Sci., 2011, 4, 1621.

8 M. M. Thackeray, Prog. Solid State Chem., 1997, 25, 1.

9 P. Kalyani, S. Chitra, T. Mohan and S. Gopukumar, J. Power Sources, 1999, 80, 103.

10 A. D. Robertson and P. G. Bruce, Chem. Mater., 2003, 15, 1984.

11 D. Y. W. Yu, K. Yanagida, Y. Kato and H. Nakamura, J. Electrochem. Soc., 2009, 156, A417.

12 I. Koetschou, M. N. Richard, J. R. Dahn, J. B. Soupart and J. C. Rousche, J. Electrochem. Soc., 1995, 142, 2906.

13 C.-H. Lu and H.-C. Wang, J. Eur. Ceram. Soc., 2004, 24, 717. 14 Y.-I. Jang, B. Huang, H. Wang, D. R. Sadoway and Y.-M. Chiang, J. Electrochem. Soc., 1999, 146, 3217.

15 R. J. Gummow, D. C. Liles and M. M. Thackeray, Mater. Res. Bull., 1993, 28, 1249.

16 H. Wang, Y.-I. Jang and Y.-M. Chiang, Electrochem. SolidState Lett., 1999, 2, 490. 
17 Y.-M. Chiang, H. Wang and Y.-I. Jang, Chem. Mater., 2001, 13, 53.

18 L. Croguennec, P. Deniard and R. Brec, J. Electrochem. Soc., 1997, 144, 3323.

19 P. G. Bruce, A. R. Armstrong and R. L. Gizendanner, J. Mater. Chem., 1999, 9, 193.

20 J. M. Paulsen, C. L. Thomas and J. R. Dahn, J. Electrochem. Soc., 1999, 146, 3560.

21 N. Yabuuchi, R. Hara, M. Kajiyama, K. Kubota, T. Ishigaki, A. Hoshikawa and S. Komaba, Adv. Energy Mater., 2014, 4, 1301453.

22 J. Sugiyama, T. Noritake, T. Hioki, T. Itoh, T. Hosomi and H. Yamauchi, Mater. Sci. Eng., 2001, B84, 224.

23 W. B. Holzapfel and N. S. Isaacs, High-Pressure Techniques in Chemistry and Physics, Oxford University Press, London, 1997.

24 P. F. McMillan, Nature, 2002, 1, 19.

25 I. Yamada, H. Fujii, A. Takamatsu, H. Ikeno, K. Wada, H. Tsukasaki, S. Kawaguchi, S. Mori and S. Yagi, Adv. Mater., 2017, 29, 1603004.

26 K. Mukai and I. Yamada, J. Electrochem. Soc., 2017, 164, A3590.

27 I. Yamada, K. Tsuchida, K. Ohgushi, N. Hayashi, J. Kim, N. Tsuji, R. Takahashi, M. Matsushita, N. Nishiyama, T. Inoue, T. Irifune, K. Kato, M. Takata and M. Takano, Angew. Chem., Int. Ed., 2011, 50, 6579.

28 D. Walker, M. A. Carpenter and C. M. Hitch, Am. Mineral., 1990, 75, 1020.

29 F. Izumi and K. Momma, Solid State Phenom., 2007, 130, 15. 30 K. Momma and F. Izumi, J. Appl. Crystallogr., 2011, 44, 1272. 31 Y. Makimura, T. Sasaki, T. Nonaka, Y. F. Nishimura, T. Uyama, C. Okuda, Y. Itou and Y. Takeuchi, J. Mater. Chem. A, 2016, 4, 8350.
32 A. F. Reid and A. E. Ringwood, Earth Planet. Sci. Lett., 1969, 6, 205.

33 E. Kroumova, M. I. Aroyo, J. M. Perez-Mato, A. Kirov, C. Capillas, S. Ivantchev and $\mathrm{H}$. Wondratschek, Phase Transitions, 2003, 79, 155.

34 E. Kroumova, M. I. Aroyo, J. M. Perez-Mato, A. Kirov, C. Capillas, S. Ivantchev and $\mathrm{H}$. Wondratschek, Phase Transitions, 2003, 79, 155.

35 C. M. Julien and M. Massot, Mater. Sci. Eng., 2003, B100, 69. 36 T.-J. Kim, D. Son, J. Cho and B. Park, J. Power Sources, 2006, 154, 268.

37 L. Z. Zhao, Y. W. Chen and G. R. Wang, Solid State Ionics, 2010, 181, 1399.

38 J. N. Reimers, E. W. Fuller, E. Rossen and J. R. Dahn, J. Electrochem. Soc., 1993, 142, 3396.

39 J. Cho, Chem. Mater., 2001, 13, 4537.

40 A. Van der Ven and G. Geder, Electrochem. Solid-State Lett., 2000, 3, 301.

41 A. Van der Ven and G. Ceder, J. Power Sources, 2001, 97-98, 529.

42 A. Van der Ven, J. Bhattacharya and A. A. Belak, Acc. Chem. Res., 2013, 46, 1216.

43 A. Urban, J. Lee and G. Ceder, Adv. Energy Mater., 2014, 4, 1400478.

44 R. Malik, D. Burch, M. Bazant and G. Ceder, Nano Lett., 2010, 10, 4123.

45 Y.-I. Jang, B. Huang, F. C. Chou, D. R. Sadoway and Y.-M. Chaing, J. Appl. Phys., 2000, 87, 7382.

46 W. Du, Z. Su and Y. Zhang, Ceram. Int., 2016, 42, 6500. 47 M. Ama, Z. Su and H. Pan, Ceram. Int., 2015, 41, 13887. 